\title{
CKD OPERACE V AUTOMOBILOVÉM PRŮMYSLU
}

\section{Zuzana Cyprichová}

\section{Klíčová slova:}

logistický řetězec, konsolidační centrum, komponenty, nejvyšší stupeň rozloženosti, standardizované balení, výrobní plán, montážní linka, kombinovaná přeprava, kontejnerové překladiště, zkompletovaná jednotka

\section{Key words:}

logistic chain, consolidation centre, components, completely-knocked-down, standardized packaging, production plan, assembly line, combined transport, container terminal, assembled unit

\begin{abstract}
Abstrakt
Článek se zabývá charakteristikou operací CKD neboli „Completely-Knocked-Down”, které představují dodávku dílů a komponentů v nejvyšším stupni rozloženosti v rámci logistického řetězce. Dále se zmiňují také o SKD tedy „Semi-Knocked-Down“ operacích, které představují nižší stupeň rozloženosti. Oba typy operací jsou typické pro automobilovou výrobu. CKD centrum zajišt'uje př́pravu, balení a expedici dílů v standardizovaných obalech. K doručení CKD dílů je možné využit všechny možnosti kombinované kontejnerové přepravy tj. námořní, železniční, silniční, popř́ipadě přepravy letecké. Kompletace automobilů pak probíhá technologickým procesem srovnatelným s klasickým mateřským montážním závodem. Opakem CKD operací jsou operace CBU neboli Completely-Build-Up, při kterých jsou dodávaný zkompletované jednotky, tedy hotové automobily.
\end{abstract}

\begin{abstract}
The article deals with CKD (Completely-Knocked-Down) operations, which represent supply of completely-knocked-down parts and components in the logistic chain. SKD (SemiKnocked-Down) operations are lower level of CKD, the parts and components are semiknocked-down. Both concepts are typical for automotive industry. The CKD centre provides a preparation, packaging and shipping parts in the standard containers. All types of a combined container transport can be used for shipment of CKD parts. The technological process for car assembly is similar like the production in a parent plant. CBU (Completely-Build-Up) is reverse of CKD operations. Like CBU are delivered completely-build-up units, the finished cars.
\end{abstract}

\section{Úvod}

„Logistika reprezentuje soubor technických a organizačních operací, které umožňují plánovaní materiálových toku včetně toku informačních a časově překlenuje nejrůznější procesy v průmyslu i v obchodě.“" „Patř́ k relativně mladým vědeckým disciplinám, které kořeny je nutné hledat ve vojenství. Postupně pronikla do oblasti průmyslu a obchodu z důvodu stejné potřeby překonávat velké vzdálenosti. Začal se prosazovat nový systémový pohled na materiálové toky jako na řetězec operací probíhající v prostoru a v čase, za pomoci dobře fungujících toků informací.“2 „Logistika prochází vývojem od zaměření na distribuci, přes pokrytí jednotlivých funkcí v podniku směrem k nejnovějšímu, integrovanému pojetí.

\footnotetext{
${ }^{1}$ PERNICA, Petr. Logistický management - teorie a podniková praxe. 1. vyd. Praha : RADIX, 2001, s.206. ISBN: 80-86031-13-6.

${ }^{2}$ SIXTA, J., MAČÁT, V. Logistika teorie a praxe. Brno: Computer Press, 2005, 295 s. ISBN 80-251-0573-3.
} 
Budují se samostatné útvary logistiky, které jsou pověřované slad'ováním, popřípadě i přímou realizací všech logistických procesů v podniku. Úlohou útvaru logistiky je optimalizovat ucelené řetězce, počínajíc podnikem dodavatele potřebného materiálu a konče konečným zákazníkem.“3

„Logistiku si lze představit jako posloupnost činností zahrnujících řízení a vlastní realizaci pohybu a skladování materiálů, polotovarů a finálních výrobků. “4 Jednotlivé procesy a operace se neustále zrychlují a zdokonalují, vznikají nové moderní trendy spojené rozvojem vědy, probíhajícími procesy globalizace trhu, internacionalizace managementu a technických inovací. Kromě již obecně známých logistických nástrojů plánovaní a řízení materiálových toků ve výrobě jako Just In Time a Lean Manufacoring apod., patří mezi nové logistické trendy současnosti také CKD resp. SKD operace, které jsou předmětem mého článku.

„Označení CKD neboli „Completely-Knocked-Down” představuje dodávku dílů a komponentů $v$ nejvyšším stupni rozloženosti v rámci logistického řetězce. “5 Jednotlivé komponenty musí být v konkrétním závodu zmontovány, aby byl předmět dodávky kompletní. SKD neboli „Semi-Knocked-Down“ představují dodávky montážních setů. Mým cílem je přiblížit problematiku CKD operaci v automobilovém průmyslu, charakterizovat jejich podstatu, strukturu a význam. Předpokládám, že strategie CKD a SKD operací je využívaná u globálních automobilových výrobců. SKD operace jsou také nástrojem, který umožňuje rychle pronikání výrobců na zahraniční trhy.

\section{CKD operace}

„Hlavní cílem CKD operací je zásobování zahraničních montážních linek v automobilových závodech a zajištění co největší úspory času a nákladů. Při tomto systému jsou z logistického CKD centra, které zajišt'uje kompletní př́ípravu, standardizované balení a expedovaní dílů ve velkém stupni rozloženosti do konsolidačních center v jednotlivých závodech. ${ }^{* 6}$ Kompletace vozu pak probíhá na standardních montážních linkách technologickým procesem srovnatelným s klasickým mateřským montážním závodem.

Monitorování a kontrola CKD zásilek je obvykle uskutečňovaná prostřednictvím ERP systému, který zajišt'uje přehled o veškerých tocích materiálů po vyexpedovaní zásilek z logistického CKD centra. „Jedná se o klíčovou činnost, kdy je na základě urgentnosti dodávky materiálu, vybírán vhodný způsob přepravy, s cílem zajistit včasné dodání komponentů do konsolidačního centra dle výrobního plánu automobilky. CKD centrum a jednotlivé konsolidační centra automobilek jsou vzdálené často tisíce kilometrů. “7

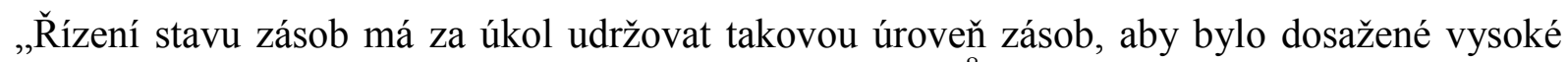
úrovně zákaznického servisu při minimálních nákladech.“8

„Nejvyšší stupeň rozloženosti představují tzv. CKD montážní sety. Při tomto systému jsou z výrobního závodu dodávány karosářské díly a další jednotlivé komponenty již ve velkém

\footnotetext{
${ }^{3}$ SIXTA, J., MAČÁT, V. Logistika teorie a praxe. Brno: Computer Press, 2005, 295 s. ISBN 80-251-0573-3.

${ }^{4}$ GROS, I. Logistika.1. vyd. Praha: VŠCHT v Praze, 1993, 1s. ISBN 80-7080-216-2.

${ }^{5}$ URL:<http://www.glovis.cz/glovis\%206.pdf>.

${ }^{6}$ URL: $<$ http://www.glovis.cz/glovis\%206.pdf $>$.

${ }^{7}$ URL:<http://www.glovis.cz/glovis\%206.pdf>.

${ }^{8}$ LAMBERT, D. M., STOCK, J. R., ELLARM, L. M. Logistika . 1. vyd. Praha: Computer Press, 2000, 20 s. ISBN 80-7226-221-1.
} 
stupni rozloženosti. Montážní závod pak zajišt’uje svaření a lakování karoserie, montáž agregátu a dalších komponentů a celkovou finalizaci vozů na standardní montážní lince. “9

„Kromě nejčastěji využívaných CKD dílů mohou být pří výrobě automobilů používané také:

- Montážní sety SKD („Semi-Knocked-Down“) tvoří kompletně vybavená karosérie, agregátu (motor, převodovka a přední náprava), zadní náprava a dalších podvozkové díly (např. kola, palivová nádrž, výfuková soustava apod.). V montážním závodě proběhne kompletace vozu a jeho důkladné prověření a testování, prováděno stejnou metodikou a za stejných podmínek, jako ve všech mateřských výrobních závodech.

- Větším stupněm rozloženosti je dále charakterizován systém MKD („MediumKnocked-Down), který obsahuje nalakovanou nevybavenou karoserii a dalších cca 1300 až 1700 dílů v různém stupni rozloženosti. Kompletace vozu probíhá na standardní montážní lince technologickým procesem srovnatelným s klasickým mateřským montážním závodem. “10

V rámci CKD se uskutečňují následující operace:

1. Ř́zení a provoz logistického CKD centra

2. Monitorovaní toku CKD dílů prostřednictví ERP systému

3. Doprava a manipulace s materiálem

4. Řizení a provoz konsolidačních center v automobilových závodech

5. Př́íprava a vychystání dílů pro kompletaci na výrobní lince

6. Uskladnění dodaných dílů

7. Export vratných obalů zpátky do CKD centra

\section{1. Ř́zení a provoz logistického CKD centra}

Cílem ř́zení a provozu logistického CKD je stabilizace a optimalizace materiálových toku a zajištění dodávek CKD komponentů do jednotlivých závodů. Jedná se velkokapacitní sklad s velkou rozlohou vybavený automatizovanou skladovací technikou. Automobilové díly jsou od dodavatelů dodávány do CKD centra, kde jsou zabalené dle požadavku jednotlivých závodů do standardizovaných přepravek, tím jsou zajištěny optimalizované podmínky, což vede ke zkrácení času pro zabalení i pro dodání. Následně jsou přepravky zabalené do palet a kontejnerů, expedovány a dopravený do konsolidačních center jednotlivých závodů.

\section{Monitorovaní toku CKD dílů prostřednictví ERP systému}

Jednotlivé skladové položky jsou označené materiálových číslem a zavedené do ERP systému. ERP systém zajišt'uje skladovou evidenci a umožňuje efektivní ř́zení materiálového toku. ERP je obvykle propojený se systémem automatické identifikace položek.

\section{Doprava a manipulace s materiálem}

„K doručení CKD dílů je možné využit všechny možnosti kombinované přepravy tj. námořní, železniční, silniční i letecké. Kombinovanou přepravu můžeme definovat jako přepravu jedné přepravní jednotky pomocí několika dopravních oborů, aniž by došlo k manipulaci s jejím obsahem. Ke kontejnerové kombinované přepravě jsou využívány kontejnery mezinárodně standardizovaných parametrů. Podle přepravovaného objemu se nejčastěji využívají 20stopé

\footnotetext{
${ }^{9}$ URL: <http://www.techtydenik.cz/detail.php?action=show\&id=131\&mark=>.

${ }^{10}$ URL: $<$ http://www.techtydenik.cz/detail.php?action=show\&id=131\&mark=>.
} 
a 40stopé, tzv. rejdařské kontejnery, případně 40stopé „High Cube“ - vyššś kontejnery pro nadrozměrné zásilky. Letecká přeprava se využívá jen při urgentních zásilkách vzhledem k její vysoké ceně. Mezinárodní námořní kontejnerová přeprava je realizovaná na základě náložného listu B/L („Bill of Landing“), mezinárodní letecká přeprava na základě AWB („Air Way Bill“), mezinárodní železniční kontejnerová přeprava na základě dohody CIM a mezinárodní silniční kontejnerová přeprava na základě Dohody CMR. “11 Přeprava z př́ístavu je organizovaná ucelenými př́mými kontejnerovými vlaky nebo prostřednictvím silniční kontejnerové přepravy. K uskladnění kontejnerů využívají automobilky externí a interní kontejnerová překladiště („Container Yard“), kde jsou kontejnery z vlaku složeny speciálními kontejnerovými překladači, stohovány a skladovány dle předem stanovených pravidel. $\mathrm{Z}$ kontejnerového překladiště jsou kontejnery $\mathrm{s}$ komponenty naváženy prostřednictvím silniční kontejnerové přepravy do konsolidačního centra.

\section{4. Ř́zení a provoz konsolidačních center $v$ automobilových závodech}

$\mathrm{Na}$ základě výrobního plánu a zásoby materiálu v konsolidačním centru závodu je prostř̌ednícím ERP systému plánované pořadí návozu jednotlivých kontejnerů na vykládku. „Hlavním cílem je plánováním výkladky a překládky kontejnerů s díly zabezpečit optimální zásobu CKD materiálu v konsolidačním centru dle požadavků výrobního plánu. Při této činnosti se zohledňuje při skladování kapacita konsolidačního centra, interních a externích kontejnerových překladišt' a rovněž časová souslednost odesílání prázdných kontejnerů zpět do př́stavu rejdařské společnosti, při čem se snaží závod vyhnout vícenákladům placeným za zdržné (,Detention Charges, Demurrage Charges”) za kontejnery. “12

\section{Př́íprava a vychystání dílů pro kompletaci na výrobní lince}

Dle požadavku výroby je materiál vybalený z přepravných obalů a vychystán na montážní linku. Díly jsou dodávaný na jednotlivé pracoviště systém Just in Time nebo Just in Sequence. $\mathrm{K}$ této operaci patř́i také pravidelné doplňovaní spotřebovaného materiálu, velice často se využívá také Kanban systém.

\section{Uskladnění dodaných dílů}

Skladování umožňuje překlenout nejenom prostor, ale i čas. Sklady jsou jedním z nejdůležitějších článků logistického řetězce a přispívají k efektivitě celého materiálového toku. Skladový informační systém zajišt'uje rychlé a spolehlivé informace o skladovém sortimentu a to jak o jeho množství a druhu, tak o jeho umístění ve skladu. Samotné zásoby představují v podniku poměrně velkou a nákladnou investici, ovlivňují zásadním způsobem cash-flow a celkovou výkonnost firmy, proto každý podnik musí uplatňovat efektivní řízení zásob.

\section{Export vratných obalů zpátky do CKD centra}

Po vybalení a spotřebovaní materiálu se obalové jednotky, které jsou vrátné, obvykle standardizované přepravky, zasílají zpátky do CBU centra $\mathrm{k}$ dalšímu použití.

\section{CBU versus CKD}

Označení CBU aneb „Completely-Build-Up“ představuje zcela zkompletovanou jednotku. Vyrobená jednotka se teda dováží či vyváží do nebo z jiné země jako kompletní automobil plně smontovaný. V rámci CBU operací automobilový závod řídí a koordinuje parkoviště

\footnotetext{
${ }^{11} \mathrm{URL}:\langle$ http://www.glovis.cz/glovis\%206.pdf>.

${ }^{12}$ URL:<http://www.glovis.cz/glovis\%206.pdf>.
} 
zkompletovaných automobilů tzv. „CBU Yard“, expedici a export automobilů ze závodu. CBU tedy představují opačný druh operace $\mathrm{k} C K D$, při kterých je automobil dodávaný v nejvyšším stupni rozloženosti. Jednotlivé komponenty jsou nejprve jako CKD díly dodané do montážního závodu v cílové zemi, kde jsou všechny tyto díly smontovány na kompletní automobil, který je $\mathrm{v}$ rámci CBU operací expedovaný ze závodu.

Z hlediska světového obchodu je významné rozlišení CBU a CKD také z hlediska velkého rozdíl u dovozních cel. V současné době jsou dovozní cla v mnohých krajinách na vozidla CBU přicházející ze zahraničí podstatně vyšší v porovnání se cly uvalenými na CKD díly. Je tomu tak z důvodu ochrany vnitřního trhu a zaměstnanosti, protože CBU nevytváŕí tolik př́ijmů a pracovních míst pro cílovou zemi. Zatím co CKD díly jsou dodávané do montážních závodů v cílové zemi, co vyžaduje investice v dané krajině do technologií, infrastruktury a lidských zdrojů, které vytváŕí podnikatelské a pracovní př́ležitosti v cílové zemi. SKD komponenty umožňují zahraničním investorům rychle pronikat na trh a dovážet díly $\mathrm{k}$ montáži osobních automobilů. Většina zahraničních investorů využíá této možnosti k rychlé expanzi a zároveň buduje továrny na průmyslovou výrobu formou CKD.

„Mnohé krajiny požadují od zahraničních výrobců určitou mírou „lokalizace“ tedy předepsaný podíl komponentů místní výroby. Ku př́ikladu skupina Wolkswagen při pronikaní na ruský trh musela splnit následující podmínky; první kontrolní termín nastává až 4,5 roku od zahájení projektu, nebo za dva roky od počátku výroby formou CKD. K tomuto termínu se podíl dovezených komponent musí snížit nejméně o $10 \%$ v cenovém vyjádření jejich celkové hodnoty. Za dalších jeden a půl roku se tento podíl musí snížit o dalších $10 \%$ a za další rok ještě o $10 \%$.“13 „Dle nejnovější úpravy ruské automobilové politiky musejí výrobci během několika let dosáhnout podílu lokálně vyrobených dílů až ve výši $60 \%$. Dále také budou muset výrobci v budoucnosti vybavovat nejméně $30 \%$ vozidel, která budou vyrobena $\mathrm{v}$ Rusku, motory domácí provenience. “14

Míra „lokalizace“ je různých zemích různá, což je také důležitý faktor, který zvažují výrobci automobilů při pronikaní na zahraniční trhy.

\section{Závěr}

„Logistické řízení se zabývá efektivním tokem surovin, zásob ve výrobě a hotových výrobků z místa vzniku do místa spotřeby. Integrální současí procesu logistického řízení je řízení oblasti materiálů, které zahrnuje správu surovin, součástek, vyrobených dílů, balících materiálů a zásob ve výrobě. Pokud podnik nezabezpečí efektivní a účinné řízení toku vstupních materiálů, výrobní proces nebude schopen vyrábět produkty za požadovanou cenu, a to v době, kdy jsou tyto produkty požadované pro distribuci zákazníkům.“15

Mezi nové trendy v logistickém řízení materiálního toku patří také CKD a SKD operace hojně využívané v automobilovém průmyslu. CKD montážní sety, tj. komponenty v nejvyšším stupni rozloženosti, jsou dodávané z logistického CKD centra do automobilových závodů $\mathrm{v}$ různých zemích. SKD sety se vyznačují menším stupněm rozloženosti než CKD díly. Úkolem CKD centra je pak příprava a expedice rozložených vozů pro zahraniční montážní závody po celém světě. CKD centrum zajišt'uje přípravu, balení a expedici v nejvyšším stupni rozloženosti. Díly jsou dodávané v standardizovaných obalech prostřednictvím kombinované

\footnotetext{
${ }^{13}$ URL:< http://www.businessinfo.cz/cz/aktuality-z-teritorii/rusky-automobilovy-prumyslapodnikatelske/13970/?rtc=3>.

${ }^{14}$ URL: <http://www.autoweek.cz/cs-aktuality-volkswagen_rozsiruje_kapacitu_ruske_tovarny-1813>.

${ }^{15}$ SIXTA, J., MAČÁT, V. Logistika teorie a praxe. Brno: Computer Press, 2005, 54-55 s. ISBN 80-251-0573-3.
} 
kontejnerové dopravy do konsolidačních center závodů, odkad' jsou distribuované dle výrobního plánu př́mo na montážní linky. Toky jednotlivých dílů a vrátných obalových jednotek jsou ř́zené a monitorované pomoci ERP systémů.

Opakem CKD operací jsou operace CBU, při kterých jsou dodávané plně zkompletované jednotky. 
Podíl komponentů ve výrobě v Hyundai Motor Manufactoring

Czech, s.r.o. dle cenového vyjádření jejich hodnoty

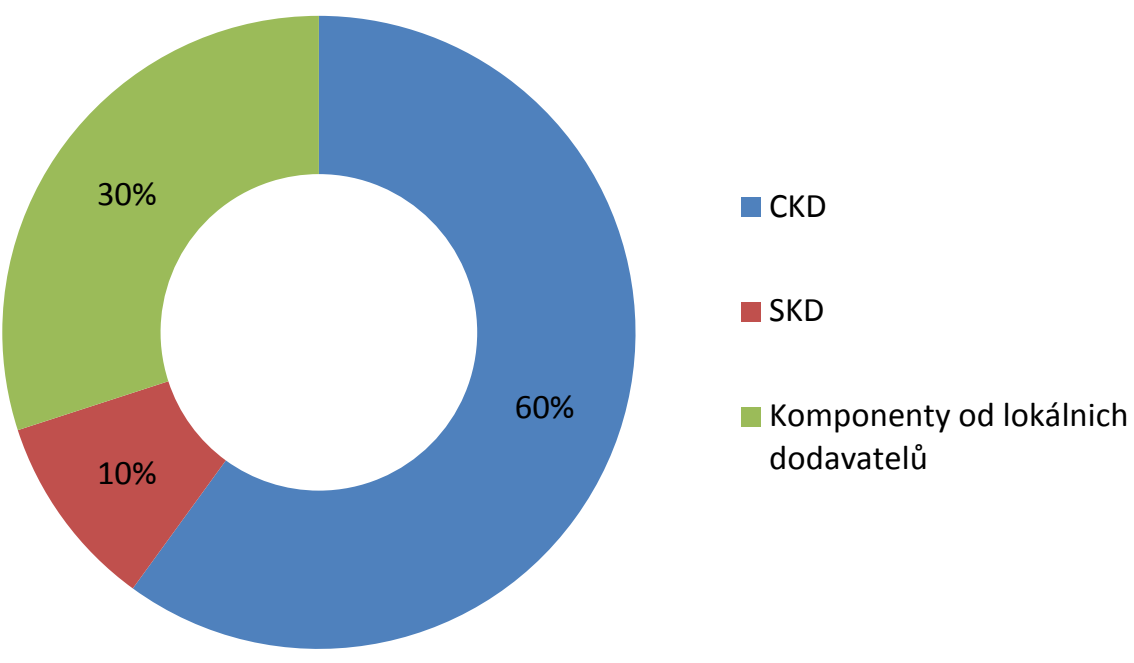

Zdroj: interní materiály Glovis Czech Republic s.r.o.

\section{Příklad evidence materiálu prostřednictví ERP systému}

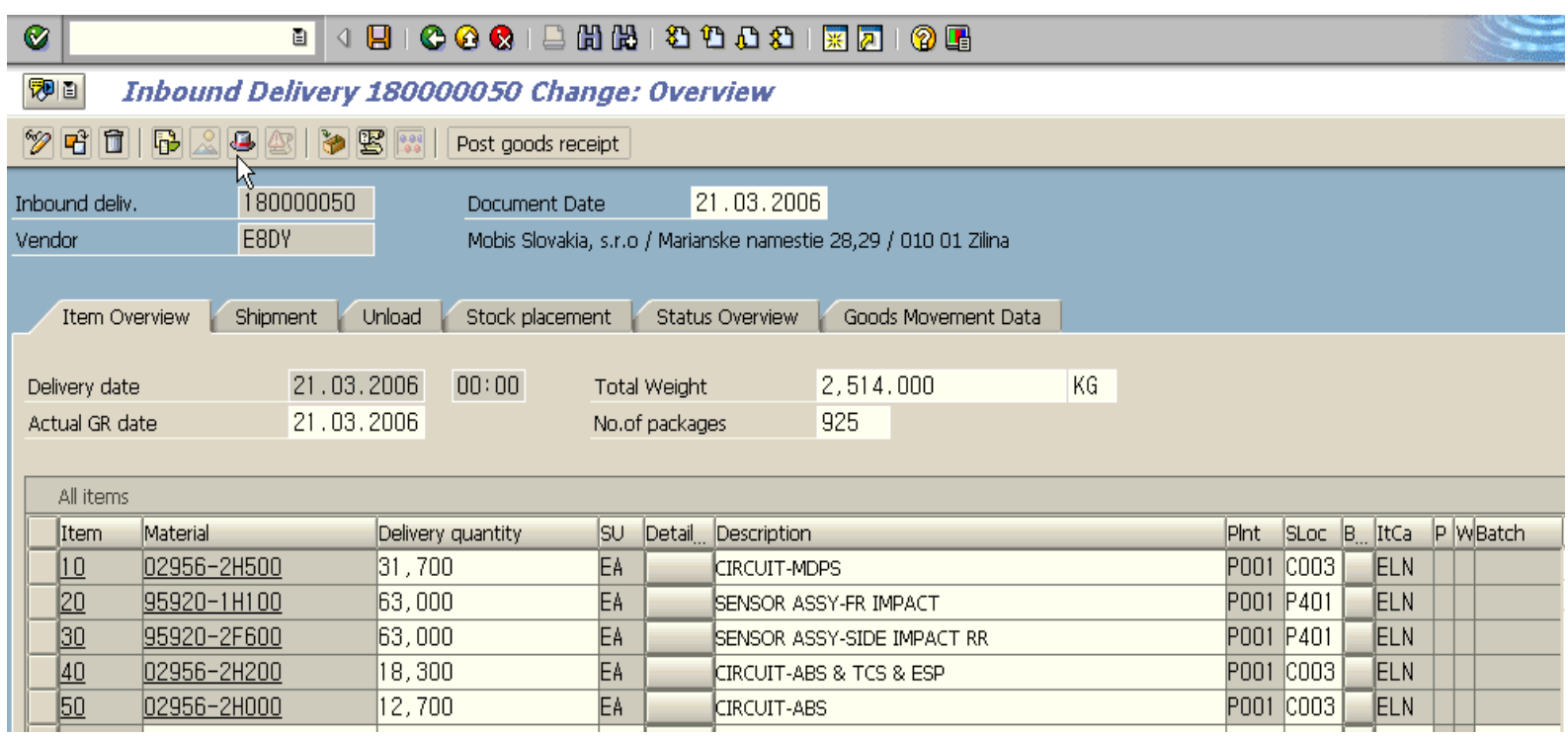

Zdroj: interní materiály Glovis Czech Republic s.r.o. 


\section{Literatura:}

[1] GROS, I. Logistika. 1. vyd. Praha: VŠCHT v Praze, 1993, 1s. ISBN 80-7080-216-2.

[2] LAMBERT, D. M., STOCK, J. R., ELLARM, L. M. Logistika. 1. vyd. Praha: Computer Press, 2000, 20 s. ISBN 80-7226-221-1.

[3] PERNICA, Petr. Logistický management - teorie a podniková praxe. 1. vyd. Praha : RADIX, 2001, s.206. ISBN: 80-86031-13-6.

[4] SIXTA, J., MAČÁT, V. Logistika teorie a praxe. Brno: Computer Press, 2005, 54-55, 295 s. ISBN 80-251-0573-3.

[5] URL: <http://www.techtydenik.cz/detail.php?action=show\&id=131\&mark=>.

[6] URL:<http://www.glovis.cz/glovis\%206.pdf>.ROS, I. Logistika.1. vyd. Praha: VŠCHT v Praze, 1993, 1s. ISBN 80-7080-216-2.

[7] URL:< http://www.businessinfo.cz/cz/aktuality-z-teritorii/rusky-automobilovy-prumyslapodnikatelske/13970/?rtc=3>.

[8] URL:<http://www.autoweek.cz/csaktualityvolkswagen_rozsiruje_kapacitu_ruske_tovarn $\mathrm{y}-1813>$.

[9] Interní materiály Glovis Czech Republic s.r.o.

Klasifikace JEL: L62

\section{Ing. Zuzana Cyprichová}

doktorand Katedra Logistiky

Obchodně podnikatelská fakulta

Slezská univerzita

Univerzitní náměstí 1934/3

73340 Karviná

zuzana_cyprichova@centrum.cz 